\title{
PENGAJARAN ANAK USIA DINI MELALUI BUKU FLANEL TERINTEGRASI DALAM BAHASA INGGRIS
}

\author{
Alfitriani, Ratna Sari Dewi, dan Rita Harisma \\ Universitas Negeri Surabaya, alfitrianisiregar@gmail.com \\ Universitas Negeri Surabaya, Ratnasaridewi@yahoo.co.id \\ Universitas Negeri Surabaya, ritaharisma1@gmail.com
}

\begin{abstract}
PAUD (Pendidikan Anak Usia Dini) adalah proses bimbingan yang sangat menentukan corak pertumbuhan dan perkembangan anak (3-6 tahun) yang sangat penting di masyarakat. Konsep pengajaran diimplementasikan dalam penataan kelas, metode pembelajaran dan kesehatan gizi anak pada tiap sekolah PAUD. Gurunya mengajarkan berbahasa Inggris dengan cara bermain dan bernyanyi tanpa alat peraga. Dan tuntutan para orang tua berlomba-lomba memasukkan anak mereka ke sekolah yang bertaraf internasional ataupun nasional plus dimana media bahasa yang digunakan adalah bahasa Inggris. Tujuan tulisan ini untuk menguasai pembelajaran bahasa Inggris per kata secara lisan dalam perkembangan Bahasa dengan menggunakan Produk Buku Flanel dalam Bahasa Inggris Edukatif yang akan memudahkan mereka untuk mengajar anak-anak usia dini. Adapun solusi tersebut: memberikan pelatihan dalam metode pengajaran bahasa Inggris Edukatif per kata dalam perkembangan bahasa anak, mengeluarkan produk Buku Flanel dalam bahasa Inggris Edukatif per kata, dan memberika pelatihan bahasa Inggris Edukatif kepada guru-guru. Beberapa metode pelaksanaan kegiatan ini adalah (1) Persiapan untuk mengikuti kegiatan pelatihan, (2) Pelaksanaan (tindakan) dalam ketrampilan menjahit dan menggunting pola yang akan membuat suatu produk dari bahan flannel menjadi alat peraga (bantu) mengajar, (3) Observasi tindakan dengan mengerjakan ketrampilan menjahit dan menggunting pola yang dibuat menjadi "buku flannel", (4) Evaluasi kesiapan guru-guru menggunakan produk sangat baik, (5) Dan refleksi sangat antusias dengan kegiatan pelatihan dapat membuat kreasi yang lain dengan bahan flannel, karena bahan flannel ini lembut, tidak berbau, tidak tajam, berwarna- warni, dan aman untuk anak-anak.
\end{abstract}

Kata kunci: AUD, Perkembangan Bahasa, Bahan Flannel

\section{PENDAHULUAN}

Pendidikan merupakan aset penting bagi kemajuan sebuah bangsa, oleh karena itu setiap warga Negara Indonesia harus mengikuti jenjang pendidikan, ini 
Alfitriani, Pengajaran Anak Usia... (hIm. 104-123)

ditertulis pada Undang-undang No 20 Tahun 2003 tentang Sistem Pendidikan Nasional. Pendidikan di Indonesia dilakukan secara terstruktur maupun tidak terstruktur. Salah satu pendidikan formal/informal untuk anak usia dini pada umur 3-6 tahun adalah TK (Taman Kanak-Kanak), RA (Raudhatul Athfal), PAUD (Pendidikan Anak Usia dini). Menurut peraturan pemerintah RI no 27 tahun 1990 tentang pendidikan prasekolah bahwa program kegiatan belajar anak usia dini meliputi aspek-aspek sebagai berikut; moral, agama, disiplin, kemampuan berbahasa, daya piker, daya cipta, emosi, kemampuan bermasyarakat, sosial, ketrampilan, jasmani.

Dalam bidang pendidikan anak memerlukan pelayanan untuk pemenuhan kebutuhan dan mengenai karakteristik anak sesuai pertumbuhan dan perkembangan anak sesuai proses belajar anak. Menurut Dian Noviayanti (2014) karena ketika anak beranjak dewasa, mereka bukan hanya belajar berjalan, namun juga berlari dan melompat. Mereka tidak hanya pandai berbicara, namun juga mampu berdebat dan berdalih. Mereka tidak saja lepas dari dekapan ibu, namun sudah menjadi sosok yang berbeda. Anak-anak mulai berubah sesuai perkembangan dan pertumbuhan ketika beranjak dewasa, mereka lebih membutuhkan perhatian penuh dari sosok orangtua dalam melaksanakan pendidikan mereka.

Ada dua tujuan diselenggarakannya pendidikan anak usia dini dikalangan masyarakan: tujuan utama untuk membentuk anak berkualitas, bahwa anak yang tumbuh dan berkembang sesuai dengan tingkat perkembangannya sehingga memiliki kesiapan yang optimal didalam memasuki Pendidikan Dasar serta mengarungi kehidupan dimasa dewasa. Kemudian tujuan yang lain untuk penyerta bahwa membantu menyiapkan anak dalam mencapai kesiapan belajar (akademik) di sekolah. 
Pendidikan semakin menjadi keperluan mendasar dalam kehidupan anak. Seiring dengan perkembangan dunia pendidikan, PAUD (Pendidikan Anak Usia Dini) kini dipandang sebagai salah satu pendidikan anak usia dini (3-6 tahun) yang sangat penting di masyarakat. Terbukti dengan semakin banyaknya penyelenggara PAUD seperti Tempat Penitipan Anak (TPA), Play Group dan Taman Kanak Kanak (TK) telah didirikan baik di pusat-pusat kota, dan desa-desa terpencil.

Menurut Agung Triharsono (2013) didalam bukunya bahwa Jean Piaget, mempunyai tahapan intelektual anak terbagi dalam kelompok-kelompoknya:

1. Usia anak 0-2 tahun, disebut masa sensorimotor

- Kemampuan berpikir ditunjukkan melalui gerakan atau perbuatan.

- Anak pada tahap sensori motor memiliki keinginan sangat besar untuk menyentuh atau memegang.

- Pada masa ini anak dengan panca indranya mempunyai peran yang sangat besar.

- Anak pada tahapan perkembangan intelektual sensori motor belum mengerti motivasi dan senjata mereka adalah dengan tangisan.

- Untuk mengajar anak pada tahap sensori motor maka dapat dilakukan dengan gambar atau sesuatu yang bergerak.

2. Usia 2-7 tahun, disebut masa pra operasional

- Kemampuan skema kognitif anak pada tahapan perkembangan intelektual pra operasional sangat terbatas. 
Alfitriani, Pengajaran Anak Usia... (hIm. 104-123)

- Yang menarik dari mereka pada tahap pra operasional adalah kesukaan mereka dalam meniru perilaku orang lain.

- Perkembangan dari segi kebahasaan menunjukkan mereka pada tahap pra operasional telah mampu menggunakan kata-kata dan kalimat pendek dengan benar.

- Anak-anak yang duduk di Kelompok Bermain, PAUD (Pendidikan Anak Usia Dini) atau TK (Taman Kanak-Kanak) berada pada tahap pra operasional.

3. Usia 7-11 tahun, disebut operasional konkret

- Anak-anak yang duduk di bangku Taman Kanak-Kanak akhir (TK) dan SD (Sekolah Dasar) sedang berada pada tahap operasional konkret.

- Pada dasarnya mereka yang sedang berada pada tahap perkembangan intelektual operasional konkret mulai dapat memahami aspek-aspek kumulatif materi.

- Mereka dengan tahap intelektual operasional konkret sudah dapat berpikir sistematis tentang beragam benda dan peristiwa yang bersifat konkret.

- Anak mulai mempertimbangkan beberapa aspek dari suatu permasalahan untuk bisa memecahkannya.

- Mereka dapat memahami bahwa kuantitas, panjang, atau jumlah bendabenda adalah tidak berhubungan dengan pengaturan atau tampilan dari objek atau benda-benda tersebut.

4. Usia 11-14 tahun, disebut masa formal operasional 
- Tahap ini mulai dialami anak dalam usia sebelas tahun (saat pubertas) dan terus berlanjut sampai dewasa dan menandai masuknya ke dunia dewasa secara fisiologis, kognitif, penalaran moral, perkembangan psikoseksual, dan perkembangan sosial.

- Anak dapat memahami hal-hal seperti cinta, bukti logis, dan nilai.

- PeMereka dengan tahapan perkembangan intelektual operasional formal mempunyai kemampuan dalam mengkoordinasi 2 jenis kemampuan kognitif.

- Contoh dari kemampuan mengkoordinasi 2 jenis kemampuan kognitif ini misalnya kapasitas dalam membuat rumusan hipotetik dan penggunaan prinsip-prinsip yang bersifat abstrak.

Namun hanya dua tahapan yang dimiliki anak usia dini pada tahapan pertama dan kedua. Tahapan jenjang pendidikan mereka dengan cara bermain, atau belajar sambil bermain. Permainan- permainan yang kreatif dan edukatif sangat diperlukan untuk perkembangan kecerdasan anak usia dini. Peran pengajar dapat memilah milih permainan sesuai kebutuhan anak.

Pengajar yang mengajar di sekolah yang berstandart internasional harus mampu mengajar dengan menggunakan Bahasa Inggris atau Bilingual Language (dua Bahasa). Pengajar-pengajar dilemma adanya tuntutan orangtua yang sekolahnya hanya standart nasional, bahwa praktek mengajar mereka hanya menggunakan Bahasa Nasional atau Bahasa Indonesia. Ada beberapa teknik pengajaran yang dilakukan oleh guru-guru PAUD yang kurang sesuai dengan usia anak- anak. Misalnya, masih banyak guru yang mengajarkan bahasa Inggris pada level "form" dari pada "content". Ada pula yang menekankan pembelajaran vocabulary atau kosakata dengan metode penerjemahan kata per kata yang oleh sebagian besar ahli pengajaran bahasa Inggris untuk anak-anak dianggap kurang 108 | http://journal.unesa.ac.id/index.php/paramasastra 
Alfitriani, Pengajaran Anak Usia... (hIm. 104-123)

strategis dan tidak natural. Seharusnya, pembelajaran bahasa Inggris sebagai bahasa asing diharapkan meniru, walaupun tak mungkin sama, proses pemerolehan bahasa ibu dimana aspek otentisitas bahasa dan naturalitas konteks harus menjadi 2 pijakan penting. Pendidikan ini hanya mementingkan aspek kognitif dan Bahasa dan mengabaikan faktor emosi.

Pengajar dapat mengajarkan Bahasa Inggris dengan menggunakan permainan dengan memilah-milah jenis kegiatan bermain dan waktu yang tepat sesuai tahap perkembangan anak. Banyak sentra-sentra PAUD yang mengajarkan bahasa Inggris sebagai muatan tambahan lebih awal. Menurut Syarifuddin (2011) menyatakan bahwa pertumbuhan anak-anak sangat dinamis, mereka seakan-akan tidak berhenti bergerak, merangkak, berjalan, berlari dan meraih apa saja yang menarik perhatiannya. Bahkan diberikan Alat Peraga Edukatif seperti bendabenda, mereka memperhatikan, diremas-remas, dilempar, diambil lagi dan sebagainya. Contoh permainan anak yang kecil dari bahan kain flannel sebagai Alat Peraga Edukatif.

Terdapat di salah satu PAUD di kecamatan Medan Kota guru-guru mengajar anak-anak tanpa gambar. Ada pula yang menggunakan gambar yang berbahan cepat rusak dan tidak tahan lama. Anak-anak sangat antusias pada gambar yang telah dibuatnya dalam karyanya sendiri, namun mereka hanya mengetahui itu adalah gambar dengan kertas berwarna-warni. Menurut Agung (2013) menjelaskan bahwa anak dapat memilah permainannya sesuai dengan perkembangan emosi dan sosial anak, perkembangan motorik, dan perkembangan bahasa. Mereka membuat untuk melatih perkembangan motorik halus dengan latihan tugas yang diberikan guru seperti: menggunting, melipat, dan melengketkan kertas. Namun, kegiatan tersebut tidak melatih perkembangan Bahasa, untuk dapat melatih perkembangan Bahasa dan perkembangan motorik 
anak dapat diaplikasikan dengan menggunakan Flannel Book yang terintegrasi dalam Bahasa Inggris. Maka kegiatan ini bertujuan untuk memberikan metode pengajaran per kata pada perkembangan bahasa anak melalui Flannel Book dalam Bahasa Inggris kepada guru-guru PAUD di kota Medan, Sumatera Utara. Pada alur proses penyusunan kegiatan tersebut:

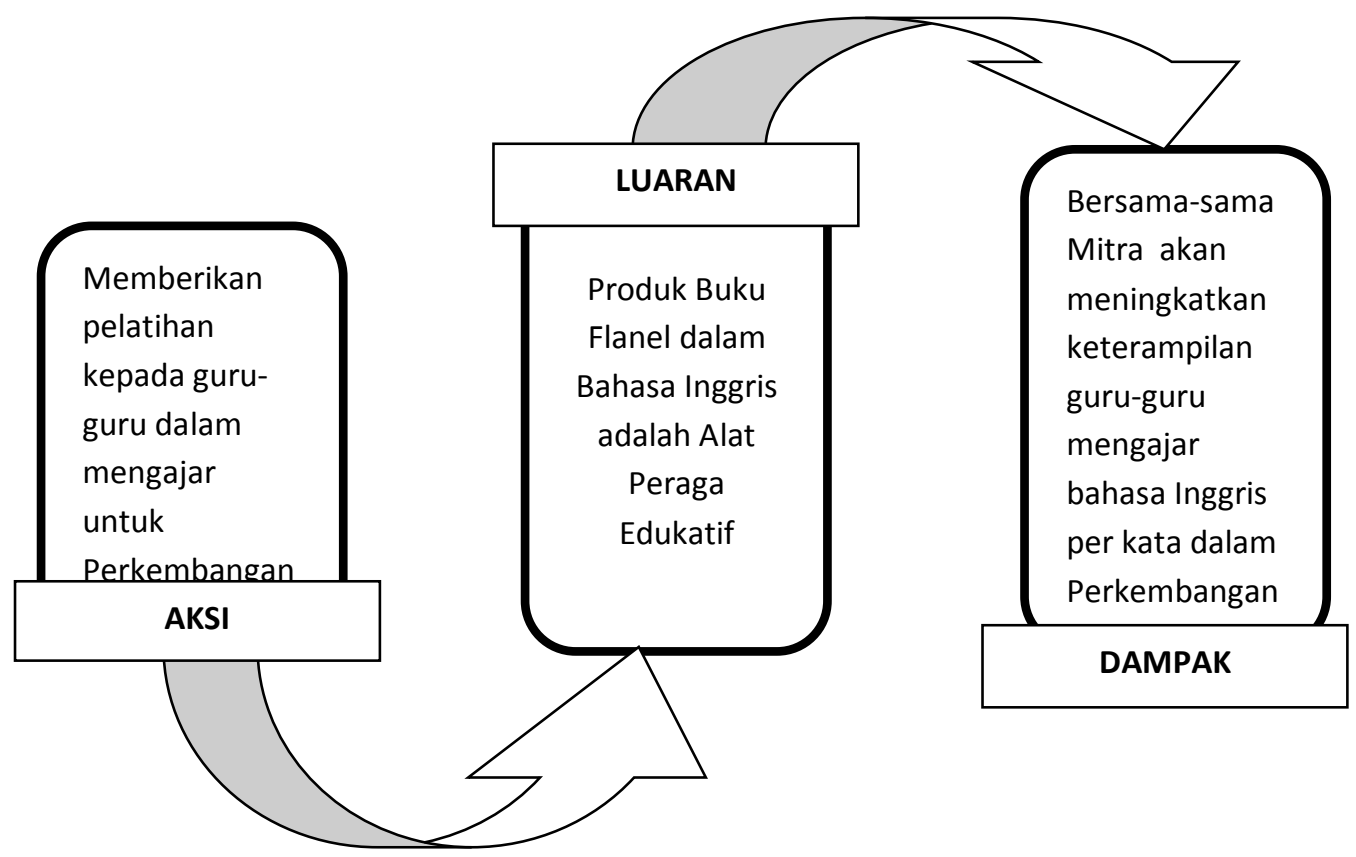

\section{PENDIDIKAN ANAK USIA DINI}

Anak Usia dini dapat belajar sesuai tahap perkembangannya dengan adanya stimulasi yang dibutuhkan masing-masing anak. Pendidikan Anak Usia dini (PAUD) diberikan kepada anak usia 3-6 tahun. PAUD memiliki fungsi utama mengembangkan semua aspek perkembangan anak, meliputi perkembangan kognitif, bahasa, fisik (motorik kasar dan halus), sosial dan emosional. Perkembangan anak di dunia pendidikannya dapat menstimulasi dengan beberapa motivasi; 
Alfitriani, Pengajaran Anak Usia... (hIm. 104-123)

1. Mengenalkan dunia sekolah

Pengalaman belajar di sekolah akan membantu anak untuk lebih siap dalam menerima pelajaran formal di bangku pendidikan selanjutnya. Hal ini yang menjadi salah satu alasan UNESCO merekomendasikan setiap anak mendapatkan pendidikan anak usia dini pada usia pra sekolah. Lingkungan belajar di sekolah tentu berbeda dengan lingkungan di rumah. Pendidikan Anak Usia Dini dapat menjembatani perbedaan suasana di kedua tempat tersebut. Anak akan belajar berinteraksi dengan teman sebayanya dan belajar beradaptasi dengan rutinitas. Anak yang sebelumnya mendapatkan pendidikan di PAUD sering kali memiliki kemampuan yang lebih baik dalam berkomunikasi pada saat sekolah. Hal ini dikarenakan ia sudah terbiasa untuk bermain, belajar, hingga makan bersama dengan teman yang memiliki usia sebaya.

2. Membiasakan anak dengan kegiatan terstruktur

Kegiatan anak di sekolah membiasakan mereka untuk melakukan dengan disiplin. Walaupun dengan kegiatan disiplin anak harus disesuaikan dengan kegiatan yang diadakan di RA, TK, dan PAUD, dirancang khusus agar sesuai dengan fungsi pendidikan anak usia dini. Salah satu tujuannya adalah melatih anak agar terbiasa terhadap rutinitas dan kegiatan-kegiatan terstruktur. Misalnya, anak akan belajar berolahraga, berbaris, menyusun puzzle, dan sebagainya.

3. Mengajari untuk disiplin

Kegiatan dirumah akan terbiasa ketika anak bermain di Sekolah, dan tentunya terbiasa bermain sesuka hati. Mereka juga mungkin sudah terbiasa mengikuti "aturan" yang telah ditetapkan, yang biasanya tergolong lentur dibandingkan "aturan" yang terdapat di luar rumah. Pada saat usia pra sekolah adalah saat yang tepat baginya untuk belajar mengikuti pola kegiatan maupun aturan lain di luar rumah. Mengikuti kegiatan pendidikan anak usia dini akan melatihnya beradaptasi dengan lingkungan baru dan peraturan baru. Mereka juga akan belajar berbagi, 
mengantri, menunggu, dan memahami bahwa ternyata tidak semua hal yang anak inginkan bisa anak akan dapatkan. Dengan begitu, mereka tidak akan kaget atau stres saat masuk dijenjang pendidikan dasar dan harus belajar dalam situasi yang sangat terstruktur dan menuntut kedisiplinan.

4. Memberikan belajar yang kreatif

Proses pembelajaran anak usia dini berbeda dengan pendidikan selanjutnya. Anak tidak membutuhkan proses yang sistematis ataupun konkret, mereka hanya melakukan kegiatan belajar sambil bermain, mencermati garis, warna bentuk dan tekstur melalui kegiatan seni yang edukatif dan membutuhkan kreatifitas dan ketrampilan pengajar. Pengajar harus memberikan cara belajar kreatif, sehingga anak dapat betah belajar di sekolahnya. Misalnya memberikan pelajaran membaca bukan hanya mengenalkan mereka pada "kosa kata" namun menyediakan media dengan kreatif dan edukatif pada anak. Sehingga mereka tidak jenuh pada tulisantulisan yang akan dibaca.

5. Pembelajaran Aktif dan menarik

Proses pembelajaran yang aktif akan memungkinkan anak melihat langsung, mengonsolidasi dan menginternalisasi informasi yang datang lebih menarik buat anak. Seperti, anak ketika kunjungan ke kebun binatang, mereka diajarkan untuk mencari tau informasi bentuk binatang, panjang ekor, lebar telinga, tajam kuku dan gigi taring binatang tersebut. Mereka diberi pertanyaan atau tanyakan pada mereka

6. Menumbuhkan nilai-nilai karakter

Kegiatan yang diadakan di sekolah pendidikan anak usia dini bertujuan untuk menanamkan nilai-nilai positif kepada anak, seperti kejujuran, toleransi, berbagi, dan sebagainya. Pada usia pra sekolah, anak belajar dengan cara bermain. Maka dari itu, kegiatan yang dilakukan di sekolah dirancang layaknya permainan, meski sebenarnya menyimpan maksud pembelajaran tertentu. Melalui berbagai 
Alfitriani, Pengajaran Anak Usia... (hIm. 104-123)

permainan tersebut, anak akan belajar tentang sopan santun, menghormati orang lain, berbagi dengan orang lain, pentingnya bersikap jujur, dan lain-lain.

7. Sarana-prasarana aman, nyaman

Tempat pendidikan anak usia dini seperti TK, RA dan PAUD adalah suasana belajar yang memenuhi kebutuhan dalam perkembangn dan pertumbuhan anak. Adanya permainan di luar ruangan (out door) disesuaikan untuk seusia mereka, tidak terlalu tinggi, tidak licin atau tidak tajam dan berbahaya. Sedangkan permainan didalam ruangan (indoor) membutuhkan banyak kegiatan motorik halus anak, permainan didalam ruangan tidak berbau kimia atau tidak berbahan organik yang dapat dipegang anak. Sehingga mereka dapat bermain out door dan in door yang aman dan nyaman.

\section{Perkembangan Bahasa}

Menurut Jeans Aitchison (2012) bahwa "Language is patterned system of arbitrary sound signals, characterized by structure dependence, creativity, displacement, duality, and cultural transmission", artinya bahasa adalah sistem yang terbentuk dari isyarat suara yang telah disepakati, yang ditandai dengan struktur yang saling tergantung, kreatifitas, penempatan, dualitas dan penyebaran budaya. Maka sebagai contoh bahasa bayi ialah mempunyai bunyi-bunyi isyarat tersendiri.

Pengertian bahasa adalah lambang dan tanda (Barber, 1972), struktur dan makna yang bebas dari penggunanya (Harun, Mansyur \& Suratno, 2009), sering sukar dibedakan dengan kata suara yang biasa kita dengar sehari-hari (Kridalaksana, 1983), digunakan oleh semua orang atau anggota masyarakat untuk bekerjasama, berinteraksi, dan mengidentifikasi diri dalam bentuk percakapan yang baik, tingkah laku yang baik, sopan santun yang baik (Hasan Alwi, 2002). Dari beberapa pendapat disimpulkan bahasa adalah bunyi, tanda, dan makna yang 
digunakan berkomunikasi setiap hari. Dan ini dijelaskan dalam kajian linguistik dibagi menjadi:

- Fonologi adalah sistem bunyi bahasa, mencakup bunyi-bunyi yang digunakan dan bagaimana bunyi-bunyi tersebut dikombinasikan (Menn dan StoelGammon, 2005). Contohnya, bahasa Inggris memiliki bunyi "sp", "ba", dan "ar", tetapi rangkaian bunyi "zx" dan "qp" tidak ada. Sebuah fenom adalah unit dasar dari suara suara dalam suatu bahasa; fonem adalah unit terkecil dari suara yang mempengaruhi makna. Contoh yang baik dari fonem bahasa Inggris adalah /k/, yakni suara yang direpresentasikan oleh huruf " $\mathrm{k}$ " di dalam kata "ski" dan huruf c dalam kata "cat". Bunyi /k/ hanya berbeda sedikit dalam kedua kata tersebut, dan dalam beberapa bahasa seperti bahasa Arab, dua bunyi tersebut merupakan fonem-fonem yang berbeda. Akan tetapi, variasi ini tidak dibedakan dalam bahasa Inggris, dan bunyi /k/ adalah sebuah fenom tunggal.

- Morfologi adalah sistem dari unit-unit bermakna yang membentuk formasi kata. Sebuah morfem adalah unit terkecil yang masih memiliki makna; yang berupa kata (atau bagian kata) yang tidak dapat dipecah lagi menjadi bagian bermakna yang lebih kecil. Setiap kata dalam bahasa Inggris terdiri dari satu morfem atau lebih. Beberapa kata terdiri atas sebuah morfem tunggal (contohnya kata "help"), sedangkan kata-kata yang lain dapat terdiri dari lebih dari satu morfem (contohnya, "helper", yang terdiri dari dua morfem, yaitu "help"+"er", dengan morfem "-er" berarti "seseorang yang” dalam bahasa Inggris“helper" berarti "one who helps" (seseorang yang menolong)). Jadi, tidak semua morfem adalah kata-kata yang berdiri sendiri; contohnya "-pre", “-tion”, dan “-ing” (dalam bahasa Inggris ) juga merupakan morfem.

Sebagaimana aturan yang menentukan fonologi mendeskripsikan rangkaian suara yang dapat terjadi dalam suatu bahasa, aturan morfologi mendeskripsikan bagaimana unit-unit yang bermakna (morfem-morfem) dapat 
Alfitriani, Pengajaran Anak Usia... (hIm. 104-123)

dikombinasikan dalam kata-kata (Tager-Flusberg, 2005). Morfem-morfem memiliki banyak tugas dalam tata bahasa, seperti menandai "tense" (keterangan waktu dalam bahasa Inggris), (contohnya, "she walks"dengan "she walked") dan "jumlah" (contohnya, "she walks" dan "they walk").

- Sintaksis adalah cara mengkombinasikan kata-kata agar membentuk frasafrasa dan kalimat-kalimat yang dapat diterima. Jika seseorang berkata kepada kita, "Bob slugged Tom" (Bob meninju Tom) atau "Bob was slugged by Tom" (Bob ditinju oleh Tom). Kita mengerti siapa yang meninju dan siapa yang ditinju dalam tiap kasus tersebut karena kita memiliki suatu pemahaman sintaksis dari tata bahasa kalimat-kalimat tersebut. Kita juga memahami bahwa kalimat, "You didn’t stay, did you?” (Kamu tidak tinggal, kan?) merupakan kalimat yang dapat diterima secara tata bahasa tetapi kalimat "You didn't stay, did you?" adalah kalimat yang tidak dapat diterima secara tata bahasa serta ambigu.

- Semantik adalah sistem yang melibatkan makna dari suatu kata atau kalimat. Setiap kata memiliki sekumpulan makna semantik atau atribut-atribut penting terkait makna kata. Girl (anak perempuan) dan women (wanita), contohnya, memiliki kesamaan ciri semantik tetapi berbeda secara semantik dalam hal usia.

Kata-kata memiliki keterbatasan semantik dalam cara mereka digunakan dalam kalimat (Pan, 2005). Kalimat "the bicycle talked the boy into buying a candy bar" (sepeda membujuk anak laki-laki membeli sekaleng permen) secara sintaksis benar tetapi secara semantik tidak benar. Kalimat tersebut melanggar pengetahuan semantik kita bahwa sepeda tidak dapat berbicara.

Pragmatik yaitu penggunaan bahasa yang tepat dalam konteks-konteks yang berbeda. Pragmatik meliputi banyak wilayah artinya harus disesuaikan dengan situasi dan kondisi, seperti ketika berbicara dengan seorang guru atau 
menceritakan suatu cerita yang menarik, lelucon yang lucu dan kebohongan yang memperdayakan. Dalam tiap-tiap kasus tersebut, kita mendemonstrasikan bahwa kita memahami aturan-aturan budaya dalam menyesuaikan bahasa dengan konteknya.

\section{Keterampilan Berbahan Flannel}

Flanel atau felt (flannel) adalah jenis kain yang dibuat dari serat wol tanpa ditenun, dibuat dengan proses pemanasan dan penguapan sehingga menghasilkan kain dengan beragam tekstur dan jenis. Flannel Book merupakan suatu alat permainan edukatif (APE) untuk anak usia dini dirancang sesuai dengan pemikiran yang mendalam dan disesuaikan dengan rentang usia. Menurut pendapat Santoso (2002) mengenai APE yaitu: Segala sesuatu yang dapat digunakan sebagai sarana/media untuk bermain yang mengandung nilai pendidikan (edukatif) dan dapat mengembangkan seluruh kemampuan anak. Pada usia anak 2-7 tahun anak umumnya dapat mengingat konsep sederhana sehingga anak suka kegiatan menyimpan \& mengeluarkan benda, mencari benda yang disembunyikan, menirukan suara yang menarik dan melihat gambar.

Bahan Flanel yang dibuat sebagai Alat Peraga Edukatif menjadi produk Buku Flanel dalam bahasa Inggris, memudahkan anak-anak dengan mengajarkan mereka di mulai per kata. Flanel atau felt adalah jenis kain yang dibuat dari serat wol tanpa ditenun, dibuat dengan proses pemanasan dan penguapan sehingga menghasilkan kain dengan beragam tekstur dan jenis (tergantung bahan pembuatnya).

Pelatihan Alat Peraga Edukatif dari Buku Flanel dalam Bahasa Inggris membantu guru-guru PAUD memudahkan pengajaran kepada anak-anak. Peran guru akan semankin tertantang untuk mengembangkan pertumbuhan kognitif bahasa anak per kata. Selain bahasa Inggris yang akan diberikan pada anak, mereka lebih suka bermain dengan permainan seperti Alat Permainan Edukatif. Syarifuddin (2011) berpendapat bahwa mainan memberikan prilaku kognitif 
Alfitriani, Pengajaran Anak Usia... (hIm. 104-123)

(kecerdasan) dan menstimulus kreativitas anak. Mainan juga mengembangkan kemampuan fisik dan mental untuk kemudian hari.

Ada 5 tahap metode kegiatan yang telah dilaksanakan yaitu; (1) Persiapan untuk mengikuti kegiatan pelatihan, (2) Pelaksanaan (tindakan) dalam ketrampilan menjahit dan menggunting pola yang akan membuat suatu produk dari bahan flannel menjadi alat peraga (bantu) mengajar, (3) Observasi tindakan dengan mengerjakan ketrampilan menjahit dan menggunting pola yang dibuat menjadi "buku flannel”, (4) Evaluasi kesiapan guru-guru menggunakan produk sangat baik, sehingga mereka dapat memperagakan cara mengajar melalui produk "buku flannel” yang terintegrasi dalam Bahasa Inggris , (5) Dan refleksi sangat antusias dengan kegiatan pelatihan dapat membuat kreasi yang lain dengan bahan flannel, karena bahan flannel ini lembut, tidak berbau, tidak tajam, berwarna- warni, dan aman untuk anak-anak. Adapun produk buku flannel tersebut, seperti gambar 1.1

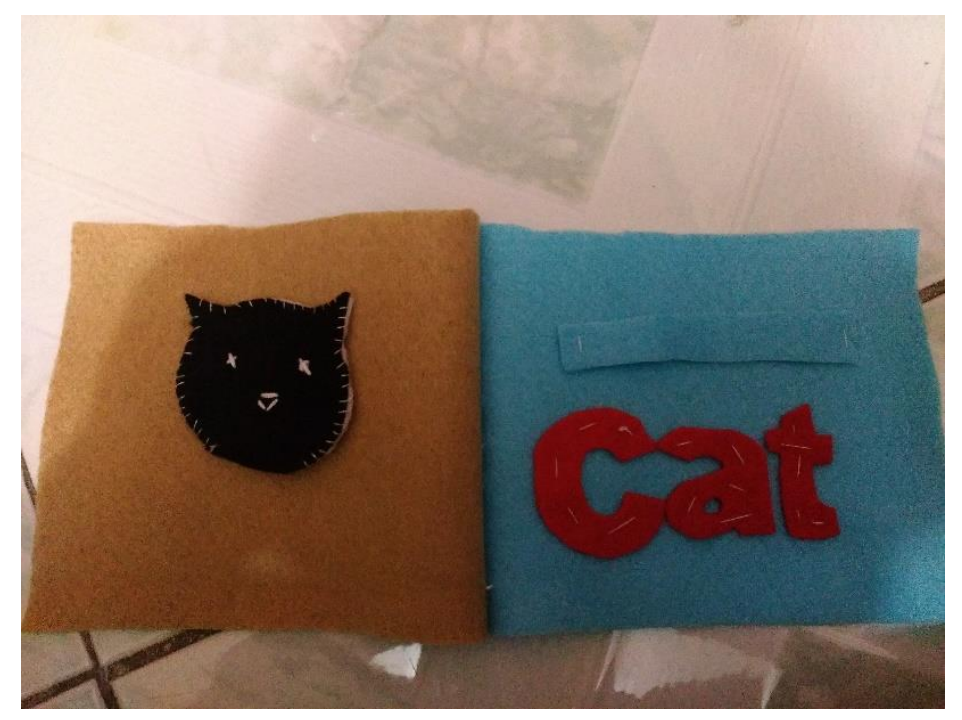




\section{HASIL DAN PEMBAHASAN}

\section{Metode Pengajaran Yang Terintegrasi Dalam Bahasa Inggris}

Kedudukan Bahasa Inggris di Indonesia merupakan bahasa asing pertama (the first foreign language). Kedudukan tersebut berbeda dengan bahasa kedua. Mustafa (2007) menyatakan bahwa bahasa kedua adalah bahasa yang dipelajari anak setelah bahasa ibunya dengan ciri bahasa tersebut digunakan dalam lingkungan masyarakat sekitar. Sedangkan bahasa asing adalah bahasa negara lain yang tidak digunakan secara umum dalam interaksi sosial.

Merujuk kepada langkah-langkah pemerolehan bahasa asing/kedua bagi anak usia dini, Haynes (2010) mengatakan bahwa paling tidak ada lima tahapan umum dan utama dalam proses pemerolehan bahasa kedua. Tahapan tersebut memiliki karakeristik dan tujuan serta esensi yang berbeda dalam konteks kuantitas dan kualitas pemerolehan bahasa tersebut.

Tahap pertama (Pre-production) yaitu tahap di mana anak kurang lebih memiliki 500 kata yang sudah diterimanya tetapi mereka belum mampu berbicara. Kadang-kadang mereka masih mengulang-ulang apa yang sudah ada tetapi pada prinsipnya mereka belum berbicara melainkan seperti membeo (parroting). Pada tahapan ini anak akan mendengar dengan penuh perhatian dan mereka sudah mampu menyalin apa yang ditulis guru. Dalam hal ini, guru harus lebih memfokuskan pada kemampuan menyimak dan penerimaan kosa kata. Di samping itu, mereka juga sudah mengerti dan mampu meniru gerak tubuh untuk menujukkan pemahaman mereka.

Tahap kedua (early production) pada tahap ini anak sudah belajar hingga lebih dari enam bulan. Anak mampu mengembangkan kosa kata reseptif dan aktif hingga mencapai hingga 1000 kata. Selama proses ini, anak-anak bisa berbicara dengan satu atau dua kelompok kata/frase. Mereka kadang-kadang sudah mampu menggunakan bahasa yang terpotong yang pendek yang telah dihafalnya, tetapi umumnya penggunaan tersebut kurang benar. Berikut adalah contoh aktivitas 
Alfitriani, Pengajaran Anak Usia... (hIm. 104-123)

yang dapat dilakukan dalam tahap ini seperti menggunakan pertanyaan yes/no question, memberikan kesempatan kepada siswa untuk berpatisipasi dalam kelas, menggunakan realita dan gambar, mengembangkan kosa kata melalui gambar, dan sebagainya.

Sejalan dengan metode/strategi yang layak dan relevan digunakan dalam proses pembelajaran bahasa asing bagi anak usia dini, menciptakan suasana kreatif, aktif, dan menyenangkan bagi anak usia dini dalam belajar bahasa asing adalah menggunakan gestures of body dan flashcards, bermain game, bermain menggunakan musik, lagu, and chants, bermain menggunakan tarian dan gerakan tubuh, bercerita peran dengan berdialog bersama, drama peran, memberikan cerita dengan memunculkan objek, kreatifitas membuat barang bekas, aktivitas seharihari menggunakan makna bilingual, menggunakan tehnologi media didalam kelas. Pendidikan bahasa Inggris akan diberikan materi sesuai perkembangan umur anak usia dini dalam materi bahasa Inggris. Berikut dijelaskan sesuai dengan table 1.1

Tabel.1: Materi Bahasa Inggris Pendidikan Anak Usia Dini

\begin{tabular}{|l|l|}
\hline \multicolumn{1}{|c|}{ Materi } & \multicolumn{1}{|c|}{ Kegiatan pembelajaran } \\
\hline Labeling & $\begin{array}{l}\text { Anak-anak memberikan nama bahan- } \\
\text { bahan yang ada di kelas }\end{array}$ \\
\hline Matching & $\begin{array}{l}\text { Anak-anak mencocokkan gambar } \\
\text { dengan objeknya yang ada di dalam } \\
\text { kelas menyebutkan namanya }\end{array}$ \\
\hline Describing Each Other & $\begin{array}{l}\text { Minta anak berdiri berhadapan. masing- } \\
\text { masing mengatakan sesuatu (parts of } \\
\text { body) }\end{array}$ \\
\hline Introduce Vegetables & $\begin{array}{l}\text { Tunjukkan pada anak-anak beberapa } \\
\text { sayuran. Bisa dalam bentuk gambar, } \\
\text { plastic atau sayuran asli. }\end{array}$ \\
\hline
\end{tabular}




\begin{tabular}{|c|c|}
\hline Making a Family Album & $\begin{array}{l}\text { Anak membawa foto anggota keluarga. } \\
\text { lalu guru menyebutkan } \\
\text { "Father" menjukkan gambar ayah, } \\
\text { "Mother" menjukkan gambar ibu, } \\
\text { "sister" menjukkan gambar saudara } \\
\text { perempuan, } \\
\text { "brother" menjukkan gambar saudara } \\
\text { laki-laki }\end{array}$ \\
\hline Song to Teach & $\begin{array}{l}\text { Anak diajarkan menyanyi lagu bahasa } \\
\text { inggris }\end{array}$ \\
\hline Job Profile & $\begin{array}{l}\text { Anak-anak menunjukkan pakaian profil } \\
\text { pekerjaan }\end{array}$ \\
\hline Responding to Questions & $\begin{array}{l}\text { Menanyakan anak-anak } \\
\text { "what is your name?, lalu membantu } \\
\text { anak-anak untuk menjawan } \\
\text { "my name....." }\end{array}$ \\
\hline Following Directions & $\begin{array}{l}\text { Minta anak melakukan satu atau dua } \\
\text { perintah dengan bergaya. contoh: } \\
\text { "up" sambil berdiri } \\
\text { "down" sambil berdiri lalu jongkok } \\
\text { "shake" sambil bergoyang-goyang } \\
\text { pinggul } \\
\text { "round" sambil putar-putar badan } \\
\text { bergerak } \\
\text { "jump" sambil lompat-lompat }\end{array}$ \\
\hline Language Experience Story & $\begin{array}{l}\text { Cerita pendek dengan gambar yang } \\
\text { besar dan jelas }\end{array}$ \\
\hline Shopping by Memory & Membawa karya \\
\hline
\end{tabular}

120 | http://journal.unesa.ac.id/index.php/paramasastra 
Alfitriani, Pengajaran Anak Usia... (hIm. 104-123)

\begin{tabular}{|l|l|}
\hline & menunjukkan benda \\
\hline What's a Pet? & Menirukan suara binatang sambil \\
& menyebutkan nama binatang contoh \\
& "auuuum" guru menyebutkan "lion" \\
"meong...meong" guru menyebutkan & \\
& "cat" \\
\hline
\end{tabular}

\section{SIMPULAN}

Pengajaran Bahasa Inggris dengan menggunakan media melalui buku flannel bagi anak usia dini merangsang mereka untuk pertumbuhan kognitif dan bahasa pada anak usia 3-6 tahun di Pendidikan Anak Usia Dini. Dengan suasana belajar sambil bermain, pembelajaran akan lebih menyenangkan. Peningkatan guru-guru dalam kegiatan ini memberikan pengajaran melalui alat permainan edukatif yang dapat mengembangkan motorik halus anak, anak dapat memegang produk buku flannel dan memainkan dengan teman-temannya. Guru dapat lebih kreatif mengembangkan ketrampilan membuat produk lain dari bahan flannel. Guru-guru dapat meningkatkan perkembangan Bahasa anak yang akan di integrasikan dalam Bahasa Inggris melalui "buku flannel" APE dengan cara bermain, bernyanyi dan bercerita atau telling story. Luaran yang didapat para guru-guru PAUD adalah produk yang dibuat Flannel Book dalam Bahasa Inggris dapat memudahkan mereka mengajar anak belajar melalui bermain (learning through play). Maka pengaruh yang terjadi kepada guru akan semankin tertantang untuk meningkatkan ketrampilan mereka dan mengembangkan pertumbuhan kognitif bahasa anak per kata. Dan sesungguhnya anak bisa menjadi kebanggaan orang tua bilamana anak tumbuh dan berkembang sesuai dengan harapan orang tua dan selaras dengan harapan Allah SWT. 


\section{DAFTAR PUSTAKA}

Aitchison, Jeans. 2012. Language Change: Progress or Decay? $4^{\text {th }}$ Edition. University Press: New York

Alfitriani. 2015. Perspektif Islam: Pengajaran Bahasa Inggris Pada Anak Usia Dini Proceedings International Workshop on Islamic Development 8th . UMSU Press. Medan ISBN: 978-602-719-958-3

Badru, Asep \& Eliyawati. 2008. Materi pokok media dan sumber belajar TK. Jakarta: Universitas Terbuka

Berko, Jean. 2005. The Development of Language $6^{\text {th }}$ edition. Boston: Pearson.

Chaer, Abdul. 2007. Linguistik Umum. Jakarta: Rineka Cipta. ISBN: 978-979$518-587-1$

Chaer, Abdul. 2007. Psikolinguistik: kajian teoretik. Jakarta: Rineka Cipta. ISBN: 978-979-518-884-1

Dimiyati, Johni. 2013. Metodologi Penelitian Pendidikan dan Aplikasi pada Pendidikan Anak Usia Dini (PAUD). Kencana: Jakarta. ISBN: 978-6029413-95-3

Gredler, Margaret E. 2011. Learning and Instruction: Teori and Aplikasi. Jakarta: Kencana. ISBN 978-602-8730-56-3

Johni. 2013. Metodologi Penelitian Pendidikan dan Aplikasinya pada Pendidikan Anak Usia Dini (PAUD). Jakarta: Kencana. ISBN 978-602-9413-95-3

Noviyanti, Dian. 2014. Anak-anak kita Pengukir Peradaban.Gramedia: Jakarta ISBN: 978-602-02-4674-1

Ottenheimer, H.J. (2006). The Anthropology of Language: An Introduction to Linguistic Anthropology. Canada: Thomas Wadsworth.

Rahmat, Aceng. 2010. Journal Kajian Linguistik dan Sastra: Implementasi Kurikulum Bahasa Asing Di Taman Kanak-kanak (TK) DKI Jakarta. Vol.22, No.1.

Santoso, Soegeng. 2002. Pendidikan Anak Usia Dini. Jakarta: Citra Pendidikan 
Alfitriani, Pengajaran Anak Usia... (hIm. 104-123)

Siraj, Saedah. 2008. Kurikulum Masa Depan. University Malaya: Kuala Lumpur.

Sonawat, Reeta \& Jasmine. 2007. Language Development for School. Mumbai: Multi-tech Publishing.

Syafaruddin, dkk. 2011. Pendidikan Sekolah: Perspektif Pendidikan Islam dan Umum. Perdana Publising: Medan. ISBN 978-602-8935-15-9

Triharso, Agung. 2013. Permainan Kreatif dan edukatif untuk Anak Usia Dini. ANDI OFFSET. Yogyakarta. ISBN 978-979-29-3386-4

Yamin, Martinis \& Jamilah. 2010. Panduan Pendidikan Anak Usia Dini. Jakarta: Gaung Persada Press. ISBN: 978-602-8807-24-1 